\title{
Erratum: The crown of virginity, paradise regained: A study of Jerome's ascetic exegesis in a selection of his works
}

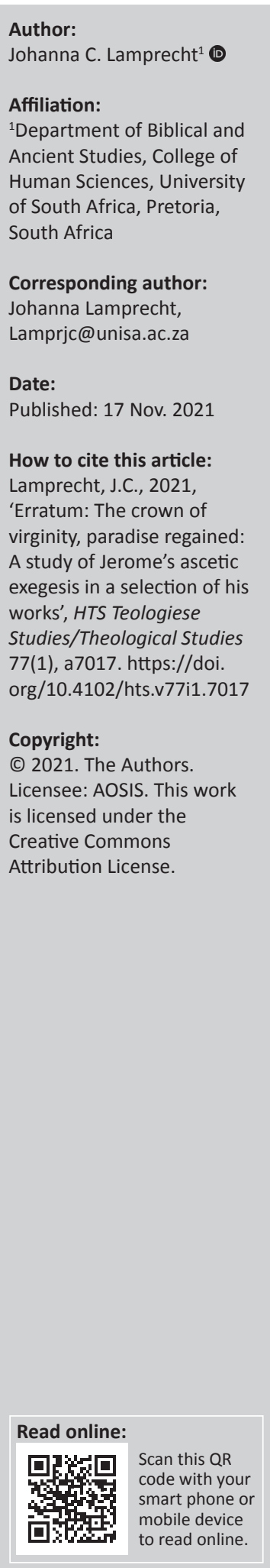

Author:

Affiliation:

${ }^{1}$ Department of Biblical and Ancient Studies, College of Human Sciences, University of South Africa, Pretoria

Johanna Lamprecht,

Date:

How to cite this article:

Lamprecht, J.C., 2021,

'Erratum: The crown of

virginity, paradise regained:

exegesis in a selection of his

works', HTS Teologiese

Studies/Theological Studies

77(1), a7017. https://doi.

(1)

Copyright:

(c) 2021. The Authors.

is licensed under the

Creative Commons

Attribution License.
In the version of this article initially published, Lamprecht, J.C., 2019, 'The crown of virginity, paradise regained: A study of Jerome's ascetic exegesis in a selection of his works', HTS Teologiese Studies/Theological Studies 75(1), a5319. https:/ / doi.org/10.4102/hts.v75i1.5319, the article section was given incorrectly. The correct section should be Original Research instead of Patient Study.

This correction does not alter the study's findings of significance or overall interpretation of the study's results. The publisher apologises for any inconvenience caused. 